\title{
Fighting for excellence: the case of the Federal University of Pelotas
}

\author{
Silvina Santana $\cdot$ Cristiane Moreira $\cdot$ Teresa Roberto $•$ \\ Flávia Azambuja
}

Published online: 3 January 2010

(C) The Author(s) 2010. This article is published with open access at Springerlink.com

\begin{abstract}
This paper investigates the implementation and evaluation of quality management systems within the higher education sector in Brazil. It is based on Institutional and Neo Institutional theories and presents the case of the Federal University of Pelotas, to discuss higher education institutions' options in a context of wide and complex environmental changes.
\end{abstract}

Keywords Higher education - Quality management · Brazilian universities ·

Institutional and neo institutional theories $\cdot$ Model of excellence $\cdot$ Public administration

\section{Introduction}

We live moments of deep and ongoing transformations, where change is the rule not the exception. Education is the focus of increasing attention and a matter of great concern to governments, community leaders, teachers, researchers, students, employers and citizens in general. Drucker (1993) aims at a definition of education with relation to its purpose, values and contents, as a need of the social and political transformations of the twenty-first

\footnotetext{
S. Santana $(\bowtie)$

Department of Economics, Management and Industrial Engineering and Institute of Electronics, Engineering and Telematics of Aveiro, University of Aveiro, Campus de Santiago, 3810-193 Aveiro, Portugal e-mail: silvina.santana@ua.pt

C. Moreira

Pro-Rector for Planning, Federal University of Pelotas and Anhanguera Educacional, Campus Porto, Pelotas, Rio Grande do Sul, Brazil
}

T. Roberto

Department of Languages and Cultures, University of Aveiro, Campus de Santiago, 3810-193 Aveiro, Portugal

F. Azambuja

Department of Informatics, Institute of Physics and Mathematics, Federal University of Pelotas, Campus Porto, Pelotas, Rio Grande do Sul, Brazil 
century. We need to learn how to define its quality and productivity, in order to measure and manage these resources. More than ever, universities are being urged to keep up with this pace. The quest for excellence in a public University should be a permanent challenge and, why not say it openly, a presupposition of its own existence.

However, for many years, quality management has focused mainly on industry. Only in the mid eighties of the twenty-fifth century, researchers began to adapt quality management's principles to the characteristics and nature of services. Consequently, many aspects developed in this context have been applied to services in a way that has not always respected their characteristics and peculiarities and public Higher Education is an illustrative example of this lack of focus.

Some authors defend that universities are characterized essentially by the qualitative nature of the services they offer, a departmental structure divided into different areas, the power of decision ensconced in schools, the autonomy of its academic units, the individualistic nature of the work that is done and the freedom that teachers enjoy as professionals and main agents of production (Meyer 1997). This profiles a complex organisation, described in the literature as a loosely coupled system (Weick 1976; Birnbaum 1988) or loosely coordinated system (Mintzberg 1979), ambiguous and anarchical (Cohen and March 2000).

In Brazil, we may unreservedly state that, in spite of the pressures, the conventional educational environment is conservative and has difficulties in responding to the socioeconomic demands of a globalized world. Most of the universities still run autocratic management models, copied from old industrial management systems, themselves inspired in military moulds, with a strong emphasis on hierarchical rigidity and the division of functions centred on order and obedience (Ramos 1995).

The new Lei de Directrizes e Bases da Educação Brasileira (Law of Directives and Basis of Brazilian Education) approved in 1996 has instituted the law for evaluation, adopting it as crucial to decision-making and quality improvement in education and in institutions. The law has introduced an important amendment, in asserting that the certification of institutions, as well as the recognition of their programs, now has limited validity and is subject to approval for renewal. This implies a periodic evaluation of all the programs as well as the universities themselves.

The Ministry of Education (MEC) is implementing the Sistema Nacional de Avaliação do Ensino Superior-SINAES (National System for the Evaluation of Higher Education), aiming at establishing a comparative base (quantitative and qualitative) among the Universities. The new system replaces the Provão: an exam applied to recently graduated students and one that has been used more or less efficiently to evaluate some of the programs of Brazilian Universities, classifying them according to the results achieved by students.

Framing and guiding the effort is the Modelo de Excelência em Administração Pública (Model of Excellence in Public Administration) that is part of the Brazilian Program of Quality in Public Administration (PQSP) and was conceived on the premise that it is necessary to be excellent while still continuing to be public. It is based on principles of quality management and ISO standards followed in several countries and bodies, namely by the European Quality Foundation.

The main goal of this paper is to investigate the implementation and evaluation of quality management systems within the higher education sector in Brazil. We discuss the rationale behind the increasing adoption of quality programs by public universities, arguing that external forces are in great part responsible for the frenzy we are witnessing and that some of them are hard-pressed to cope with the pressure. Using Institutional and Neo 
Institutional theories to underpin the discussion, we try to conceptualize Quality Management in a Public University which has organisational systems with different characteristics, classifying it as a complex organisation, in the light of the excellence criteria used in Brazil and in several other countries. The study then investigates the development of the Quality System inside the Departamento de Registos Académicos-DRA (Department of Academic Registries) of the Federal University of Pelotas (UFPel) in South Brazil. This department was chosen because it assists a great number of internal and external clients directly. It is a key element inside the institution, making the pursuit of excellence in its management, according to the externally imposed quality standards a constant challenge. We used the Model of Excellence in Public Administration that institutions are following in order to implement quality management systems, for the evaluation of management practices in the organization with the intention of diagnosing a possible gap between what is proposed externally and what is carried out in practice. Additional interviews allowed us to detect debilities in the implementation of the quality programme and to better understand the causes behind certain attitudes, motivations and behaviour.

We use a mixed methodology with quantitative and qualitative aspects and a descriptive/comparative approach, because it allows us to analyze implicit aspects in the development of organisational practices. Although several research strategies are available, we use a case study approach, here taken as an empirical study that investigates a phenomenon in its real context (Yin 2003).

We conclude that improvement demands urgent and integrated intervention with regard to several aspects, with the aim of attaining excellence in this department.

\section{The Brazilian University and the battle for quality}

The Brazilian universities are living complex situations involving, on one side, ever growing demands on the part of society and, on the other, higher education policies guided by short term, quantitative and utilitarian perspectives that are suffocating them, restricting State financing of their activities.

Challenged, universities do not seem prepared to face this new reality, since it demands deep transformations that go beyond the constraints of simple reforms. In this sense, more than analyzing their present condition, it is necessary to go deep into their structural reality, so as to promote fundamental changes which are able to overcome functional and organisational rigidity, relative impermeability to external pressures and aversion to change.

The Brazilian Public Universities are structured according to the North American model implemented by the Flexner reform (Freitag 1986; Romanelli 1991), having implemented the departmental system with the separation between institutional management brought about by the deans of the schools and faculties and academic governance, conducted by the departments and in which all the Full Professors take part. In this context the lifelong chair of the Humboldtian University disappeared but many of the characteristics of the European systems were maintained. Schwartzman (1993) defends that in adopting the Flexner model in 1968, the Brazilian legislator made two serious mistakes. The first was to ignore the tendencies of massification in higher education, already noted by Kerr in his preface to the work by Flexner (1930). The overwhelming demand for education opportunities and places, in a country with a significant number of young people among its population, led to the creation of a colossal higher education system which, although differentiated in practice, followed a monolithic and centralised model which did not include differentiation 
as a value. The second mistake was in adopting, along with the innovative concepts, what some institutions in the United States still retain from Europe: centralization, formal rationality and bureaucratic control.

As a consequence of the reform, Brazilian Public Universities follow the principle that teaching, researching and servicing are inseparable activities and enjoy didactic, scientific, administrative, financial and patrimonial autonomy. However, they are reliant on MEC and end up following autocratic management models, in which they are obliged to accept directives and to adhere to programmes that are imposed from above, in order to survive, for example, in the implementation of the Plano de Reestruturação e Expansão das Universidades Federais-(Plan for the Restructuring and Expansion of Federal Universities) REUNI (decreto lei 6096 de 24 de Abril de 2007). Internally, characteristics inherent to a loosely coupled system cohabit with autocratic management models and highly bureaucratized structures.

The complex character of their structures, as multifunctional institutions, and the planning and management challenges involved, raise serious difficulties when trying to assure acceptable levels of excellence in all the areas in which they intervene. Therefore, quality has become the central problem of the Brazilian universities that have to manage it while performing their traditional roles and functions.

Quality generates discussions regarding several interdependent and interrelated dimensions that embody all the academic processes: qualification of human resources, selection of students, teaching and employability, conditions and use of available technologies, and pedagogical practices and perspectives.

Niskier (2000) maintains that Brazil lacks an educational doctrine and posits that Brazilian authorities might not even know what this is. He sustains that only after doctrinal concepts focusing on present conditions and priorities for future actions have been established will it be possible to objectively analyse the Brazilian educational setting.

The fact that the Brazilian Universities have been unable to keep pace with changes in society at the rhythm that is expected is also pointed out. They are said to be reacting slowly to social needs and to be out of phase and in need of quick action so they can be considered quality social organisations (Tubino 1998). Yet, Public Universities are responsible for the best under-graduate and graduate programs and for almost all scientific and technological research in Brazil. It is recognisably difficulty to find an irreproachable method to classify the universities, one which takes into consideration their quality levels, but all the approaches suggested up till now demonstrate the superiority of the public Universities, according to the official evaluations performed by MEC. In short, Public Universities have been caring for the quality of teaching, researching and extension activities that involve the community in which they operate, training professionals who achieve high performances in the market (Barçante 1998). However, being an institution recognized for the quality of the professionals it puts on the market is different from being an institution that has established a dynamic process of Total Quality Management and extended it to all levels of the institution.

In a way that is paradoxical to the politics of investment limitation, the Government has been establishing directives and parameters to encourage Public Universities to move forward to a new quality level. The Coordenação de Aperfeiçoamento de Pessoal-CAPES (Coordination for Personnel Improvement) and the Coordenação Nacional de Pesquisa$\mathrm{CNPq}$ (National Coordination of Research) have been using rigorous quality criteria regarding the qualification of faculty and scientific production, privileging post-graduate courses and programs. MEC is implementing SINAES, aiming at establishing a comparative panorama among the Universities. 
Apparently, the factors hindering the implementation of quality systems are: the nature of the product and the difficulties in its evaluation, resistance to managerial approaches and to change, the individual nature of academic activity, the shared power structure, amateurism of management practice and aversion to risk and to challenges. Universities prepare future generations of professionals and citizens, reflecting the world and life in society. However, it is in these same universities that one finds the strongest resistances to the changes and transformations demanded by the society (Meyer 1997).

\section{Institutional theories in the context of higher education}

The discussion up till now foretells a complex reality to perceive, analyse and manage, because of its multipurpose, multilevel, multifunctional and multi-actor nature. Considering the subject and the aims of this research, the Institutional and Neo-institutional theories (Scott 1987; DiMaggio and Powell 1991; Meyer and Rowan 1991) were considered appropriate means to attain better understanding on the subject, for they are concerned with the manner in which certain structures act upon individuals, as factors of external pressure for change.

Institutional theories are based on the conviction that institutional environments are socially constructed. Organizations are conceptualised as open systems, which suggests that the external environment and its participants help to mould internal structures and activities (Scott 1998). Every organization depends on the establishment of relationships with larger systems from which they are separate, in order to survive. All of them exist in a specific physical, technological, cultural and social environment, to which they must adapt. Institutional theorists believed that society identifies organizations by the norms and values that exist in them (Scott 1995). They claimed that the organizations incorporate the norms of the community and the values of its social systems, a process defined as institutionalization.

Institutional Theory is based on the understanding that the degree to which the norms and values are institutionalized depends on the internal dynamics of the organization, like the level of specialization and the technical design. An additional supposition is that, for the norms and values to be institutionalized, they have to have the support of those in power and that these people also have to strengthen the norms and values by their own actions. Consequently, the leader is described as an agent of institutionalization. Assurance is also a responsibility of leaders, to define and defend the institutional norms and the values but also to ensure that they are consistent with the community. Therefore, leaders are critical in maintaining the identity of their organizations. Once institutionalized, the norms and values become a guide for the workers, signposting what is acceptable. One of the organization's actions is to express the institutionalized rules and procedures.

In short, Institutional Theory aims to explain how organizations adapt themselves or change their culture and their structure to face socially acceptable values and the way in which these values are weakened or deinstitutionalized. Hence, although there is some discussion as to the influence of the external environment, Institutional Theory tries to explain, above all, the institutionalization of normative controls as patterns of beliefs, values and norms.

Lately, institutional theories are said to be reviving (DiMaggio and Powell 1991). This revival comes about with writings by Zucker (1977), DiMaggio and Powell (1983) and Meyer and Rowan (1991). Collectively, they provide a basis for so-called Neo-Institutionalism. Neo-Institutionalism is based on the belief that external influences, like 
pre-existing socio-cultural norms, the relationships between organizations and the political sifting imposed by governments exert pressure to change the routines in organizations.

According to Neo-Institutionalism, organizations comply with procedures and practices if they are considered socially acceptable rationalizations on how to structure their operations. Rules and rational routines would be adopted by organizations to ensure that they are perceived as legitimate and not for reasons of efficiency. They would not be adopted to control behaviour and practices in the organizations but to warrant the confidence of the various entities that may be interested in their operations, boosting their capacity to attain resources, reduce the probability of their conduct being questioned and increase their chances of survival. Organizations would then strive to ensure that institutionalized routines would stay visible to external constituents.

One of the fundamental suppositions of Neo-Institutionalism is that, in order to survive, organizations need to prove their social merits in an environment in which each of them depends on the others. The responsibilities of organizations with regard to external exigencies and expectations are therefore vital and organizations will not be successful if they diverge from institutional myths.

Therefore, organizations reflect patterns and models established in a larger system. They do this to imitate the visible part of these patterns or models. As such, organizational structures are frequently copied and dependent on the level of external pressure, both political and public. Imitation makes the organization develop a particular structure. This structure is disconnected from the specific work or activity and the activity is disconnected from its effects. As a result, the activity becomes less visible and only the organizational structure is perceptible to the outside. Environmental patterns direct the organization of work by means of pairing and effects that go beyond direct or simple control, like regulations, laws and resources. Environmental patterns are significantly influential systems, made up of social patterns or cultural behaviour, of normative and constitutive rules and regulation processes, of which one has a very limited awareness. The structuring of day-today life within impersonal unified rules leads to an organization with collective aims. In this process, states and nations, organizations, sciences and professions are important conductors, who force us to operate in accordance with the norms of rationality.

However, although some researchers agree that these mediating structures mould important patterns and models, there is still some dissension on the manner in which they are imported. For Scott and Meyer (appud Scott 1987), organizations do not necessarily conform with a game of institutionalized convictions just because they are there but because they are frequently recompensed for doing this, with an increase in legitimacy, resources and the means of survival.

The structuring that takes place in organizations, based on the demands of their environment is explained by means of isomorphic practices. The organization reflects a socially constructed reality (Meyer and Rowan 1991). DiMaggio and Powell (1991) present three mechanisms of isomorphic institutional change. Coercive isomorphism is brought about by the formal and informal pressures exerted on organizations by other organizations on which the former depend and by cultural expectations in the society in which they function. Mimetic isomorphism is brought about by patterns of response to insecurity, a powerful force that encourages imitation. Lastly, normative isomorphism is related with the professional control. These changes are not always clear and can occur simultaneously.

With regard to higher education, "quality frameworks reflect the institutionalization of a series of myths about quality that universities are under increasing pressure to adhere to" (Bell and Taylor 2005). When formally imposed by external bodies, like in Brazil, they may work as powerful forces moulding the organizations. Here they are forced to show 
results according to the criteria which are externally defined, in order to sign Terms of Partnership with the State and obtain resources. Concomitantly, the implementation of REUNI entails an increase in students and in courses in a time span that disallows a compatible increase and improvement in the University structure. By making financing dependent on the immediate presentation of projects, the executive practically imposes a paradigm in which the federal universities have to offer accessible study programmes to students who come from state secondary schools and, in one way or the other, pass the majority of these students while at the same time, more temporary and less qualified teachers are engaged, as there is not a sufficient number of teachers with a $\mathrm{PhD}$ for the needs brought about by the new courses and places and due to the bureaucracy and the sluggish process in staff admissions, which will obviously have repercussions on the output quality of these organizations. For example, the UFPel will have to increase the number of places available from the present 12.000 to 20.000 by 2012 in order to attain the goals imposed by the REUNI.

Processes of coercive, mimetic and normative isomorphism are likely to take place. Levels of quality attained become an aspect of stakeholders' expectations about what constitutes a good university. Universities keep emulating each other in demonstrating good results. Workers belonging to different professional categories fight to define their working methods and conditions control the producers' production and establish a cognitive base and legitimacy for their occupational autonomy (Powell and Di Maggio 1991).

However, a new set of practices is not legitimate or illegitimate in itself. It is created or adopted to solve a problematic situation and will undergo a process of diffusion with situational characteristics and uncertain results. This might be particularly true and interesting to study within Brazilian Public Universities where, as we have demonstrated, characteristics of loosely coupled system cohabit with autocratic management models and highly bureaucratic structures. Weick (1976) believes that traits of loosely coupled or loosely coordinated systems may allow parts of the organization to persist, despite changes in the environment and provide more room for self determination by some of the actors, making it harder to systematically change the whole system. On the other hand, in more bureaucratized units and departments one should expect higher levels of adherence and compliance with the external determinations. Supported by the Institutional Theory, when arguing that the degree to which the norms and values are institutionalized depends on the internal dynamics of the organization, we can even admit that the two situations might coexist, with unforeseen repercussions at several levels.

\section{Methods}

\section{Study design}

We applied the excellence criteria defined by PQSP to the DRA. DRA is responsible for the student's academic life and management of data and information regarding graduation programs. The following services, corresponding to responsibilities and competences, have been identified: (a) emitting, registering and validating diplomas and certificates; (b) confirming registries of consulates, embassies, Federal Police and Regional Council; (c) coding new subjects; (d) controlling the enrolment process; (e) controlling class summaries; (f) registering grades; (g) assisting students and program secretaries and coordinators; (g) registering and keeping graduating student records; (h) conducting processes related with programs and subjects and (e) sending transfer documentation and vacancy certificates. 
Data collection and analysis took place during the second semester of 2004 and the Spring of 2005. In a first phase the Rector, the Vice-Rector, the Pro-Rector for Graduation, the Director of the DRA, the Coordinator of the Quality Committee, four DRA workers and ten teachers were interviewed. Afterwards, semi-structured interviews were conducted with fifteen students and five ex-students who were using the DRA services. All the DRA workers, teachers and students participating in the study were randomly selected. Direct observation and document analysis were used to collect data that could not be obtained during the interviews allowing for the triangulation of results. We analysed various internal work documents from previous years, namely, management reports, action plans, multiannual management plans and course catalogues (Appendix 1).

\section{Procedures}

Data collection was performed according to the rules defined by the Brazilian Model of Excellence for Public Administration, which includes seven blocks that compose a management system for Brazilian public sector organizations. For evaluation purposes, the seven blocks are translated into seven criteria, the Criteria of Excellence, incorporating the excellence references, from which public organisations can start to implement continuous cycles of evaluation and improvement of their management practices.

\section{The seven criteria of excellence}

The criteria are Leadership, Strategies and Plans, Citizens and Society, Information and Knowledge, People, Processes and Results. Figure 1 shows their interrelatedness.

Leadership deals with the way the leadership system is structured in the organisation, its composition and the way it operates. As an evaluation tool, it analyzes the way top administration, starting from the government's macro-orientations, act to define and disseminate values, polices and strategic orientations, among the collaborators, considering the needs of all the interested parts, guiding them in the search for institutional and individual development, stimulating initiative and creativity. It also deals with the way the top administration critically analyzes the global development of the organisation and the way the practices related to the leadership system are appraised and improved.

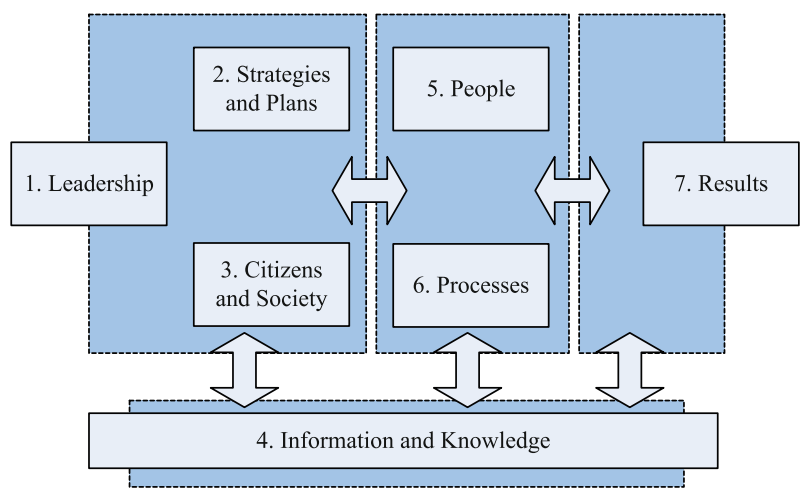

Fig. 1 The model of excellence for the Brazilian Public Administration. Source Manual de Avaliação do PQSP. Ministério do Planejamento, Orçamento e Gestão, 2004 
Strategies and Plans deals with the way the organisation, starting from its collective image and mission, formulates the strategies and unfolds them into short and long term plans of action. It approaches, particularly, the way the organisation uses information about customers and its own performance to establish strategies, assuring its alignment and correct implementation, aiming at the achievement of its mission and the satisfaction of all interested parties. The criterion also includes the way the evaluation system is defined and implemented and the way the practices related to strategy formulation, implementation and evaluation are appraised and improved.

Citizens and Society examines the way the organisation, in the execution of its institutional competences, identifies and understands the customers of its products and their respective needs, anticipating them. It deals with the way it promotes its products and actions, seeking to reinforce its institutional image and how it strengthens the relationships with the customers and measures and intensifies their satisfaction. The criterion also examines the way the organisation deals with its responsibilities to society and the communities directly affected by its activities and products and stimulates citizenship. It also reflects the way the practices related to the mutual knowledge, the relationship with the customers and the interaction with the society are appraised and improved.

Information and Knowledge measures how the organisation manages the information, the knowledge and the critical indicators concerning its own performance and the performance of its comparative referential. It also deals with the ways they are appraised and improved.

People deals with the way the organisation prepares and stimulates its employees to develop and use their full potential, in alignment with the strategies of the organisation, and the efforts made to create and maintain an environment that leads to excellence in acting, to full participation and to individual and institutional development. It also deals with the way the practices relating to the work system, training, development, and quality of life are appraised and improved.

Processes deals with the main aspects of internal operations, including the structuring of its processes according to its legal competences, the definition of its services with focus on the citizens' needs and the implementation of its core, support, financial and supply processes. Therefore, it seeks to account for the way the main processes of the organisation are defined, structured, implemented, managed and improved. The goal is to bring about better performance and citizens' satisfaction.

Results deals with the evolution of organisational performance in relation to citizens' satisfaction, considering the attendance to potential users and improvement of organisational products and processes. It evaluates people satisfaction, performance, well-being, education and training, suppliers' management, goals attainment and financial resources application. It appraises the level of performance when compared to appropriate comparative referential.

\section{Operationalization of evaluation items}

The excellence criteria are related with the phases of the PDCA cycle (Plan, Do, Check, Act) (Deming 1986): Leadership, Strategies and Plans and Citizens and Society corresponds to Plan; People and Processes to Do; Results to Check; and Information and Knowledge to Act. These criteria entail 26 items that describe the requirements demanded from the results and the management practices and are ranked on a scale that goes from 0 (zero) to 1.000 (one thousand) points. The ranking system foresees three dimensions for evaluation of the criteria and its items: in relation to the methods being used, the 
application of those methods and the results achieved. Each item is classified either in the category Methods and Application or the category Results. The three dimensions are subdivided into evaluation factors. Method is ranked according to the Adequacy of the practices and its Exemplariness. Application refers to the dissemination and use of the Method and is ranked according to the level of its Dissemination, and Continuity. Table 1 ("Appendix 2") shows how Application and Method are graded. Results refer to the consequences of the application of the Method and are ranked according to its Relevance, the actual Performance, and its Tendency. Table 2 ("Appendix 3") shows how Results are ranked.

The total score in the 26 items of the criteria (see the DRA example in Table 4, "Appendix 5") generates the global score, ranking the institution in one of the nine levels described in Table 3 ("Appendix 4").

\section{The case of the DRA of the Federal University of Pelotas}

The Quality and Productivity Committee of the UFPel was created by Decree/Order 898/ 01 of 19/11/2001 with the intent of disseminating the Quality Criteria and stimulating action in this area. Work carried out since then has allowed UFPel to obtain a Quality Certificate. The DRA was considered particularly interesting as field of research. It is the department in the University with the greatest number of internal and external clients and its actions are crucial to the good performance of a large parte of the activities that take place in the University; also, it was participating actively in this endeavour. Furthermore, most of the activities carried out are of an administrative nature, which, at the outset, eliminates some of the difficulties that are inherent to evaluating certain processes like education and research. However, the implementation and evaluation of the quality management system in a department like the DRA cannot be considered of lesser importance in the University context. The quality of an outcome depends on the quality of the product provided by each link in the system that produces it. This means evaluating all the processes which affect the functioning of an educational institution, and involving all the people (Doherty 1997). Indeed, the processes implemented in the DRA are of extreme importance in the assurance of the quality, the efficiency and the efficacy of the processes conducted in other departments, namely, those related with teaching, since they assure the existence of conditions for their functioning effectively and with the required level of quality.

On the other hand, all the process of quality assurance and evaluation in the DRA is a true case study inside the UFPel. In fact, the process of implementing a quality assurance system and its consequent evaluation has been attempted in other departments of the institution but in none of them has the expression and the continuity in time attained at the DRA been achieved. A possible reason for this situation, assumed a priori in this study was the level of commitment and involvement of high administration in the process but this was but one of the many assumptions in need of further investigation.

\section{Results from the field investigation}

The final score of DRA was 456 points (Table 4, “Appendix 5"), corresponding to level 5 in low position, meaning that the practices of the DRA are adequate and effective for some of the requisites of all the items, with some being proactive, with continuous use in many of the areas and processes. However, in some of them the application is still in its initial 
stages. There are favorable tendencies and the performance is superior to the comparable information in some of the results.

The DRA leadership system possesses a staid, inflexible structure where the more complex decisions depend on the authorisation of the Pro-Rector and the Director of the DRA. The participation of the Top Administration in the weekly meetings and in the writing up of the Management Report, the multi-annual management plan (PPG) and the annual action plan (PAA) grant it a prospect of future scenarios, allowing it to anticipate possible courses of action. Nevertheless, it is not possible to evaluate performance in this field, as there is no habit of professional management and work-patterns, considering that the leadership system has not been defined. At present there is no specific training for leaders. The values and directives of public administration as well as the values and directives of DRA are contained in the PPG and the PAA and can be perceived as parte of the organization's culture. The values and directives of the UFPel were generated over time. With the development of the management system, we sought to bring quality concepts to DRA reality, with a view to optimizing management; a commitment of all in preparing the organization for future challenges but work patterns in DRA are still in a discussion process. The data used in the planning are the records obtained through the Management Reports. DRA management is based on pertinent norms, with care to ensure that management practices are covered by documented routines, so as to direct DRA towards achieving its aims. Although there is quantitative information on the performance of Brazilian public universities, it is not analysed and these are not compared.

The DRA does not follow a specific process of strategic planning, as the formulation of strategies is taken upon by the Top Administration. It results in broad and general strategies that do not cater for the needs of DRA. Thematic structuring has still not been carried out and there is not enough information and resources to fuel the first stage, which would be the development of the strategic plan.

All the information on students' records depends on the transfer by the units and by the students themselves for updating and this occurs, in part, without established practices and in an unreliable and badly disseminated manner. The academic management system is being implemented and there are not enough knowledgeable users to operate it.

The coherence of the whole system is due to interchange practices with the programmes collegiate. There is a committee under a Pro-Rector in charge of graduation involved in creating, evaluating and putting the PAA into effect; it formulates the actions and projects and participates in all the stages of the operational process. Monitoring is carried out every 6 months, by a commission appointed by institutional ordinance. Two types of indicators are defined: administrative indicators that express monthly results of the whole department and are used to define the goals; operational indicators, which relate to processes. However, there is no integration and correlation of these indicators, as the data required by MEC is only collected. The performance projection according to the different indicators is based on the knowledge of the team members and previous reports. Starting from the established goals, the annual action plan is defined and the necessary resources are allocated to implement it.

There is still no classification of current and potential clients. Client needs are identified randomly, are not based on prior study and no indicators are assessed although there is room to innovate and improve the image and knowledge that each has of the other. Available services are made known through the Internet and by course directors. The DRA provides the most widely used communication channels on the market. These channels were established with the view to providing personalized service. Complaints are treated case-by-case but a process for the management of complaints has still not been defined. 
There are no guidelines for these services and client satisfaction is not measured. The main instruments use by the DRA to guide and encourage the community to control its results are the audits carried out by the Tribunal de Contas da União (National Accounts Court) to verify the application of public resources and budgets and the disclosure of annual management reports on the Internet. At this moment there is no action taking place in the ambit of Health and Security at Work, nor are the impacts on society evaluated. The ethical behaviour of DRA is expressed in the Estatuto de Regime Jurídico Único (Sole Charter of the Legal System) which is observed directly by the Directorship of the DRA. The DRA participates actively in projects of community interest such as the promotion of internships in its departments and the reintegration of retired members.

The DRA has invested in computerizing the whole academic system with a view to obtaining quick, dependable and consistent information that can be easily retrieved. It has spotlighted a growing proportion of computers to users, and focused on Internet access and the implementation and updating of specific applications. Nevertheless, it has still not determined its comparative information needs. Consequently, there is no structured and systematized process in action for its management. This information is fundamental for the formulation of an improvement plan, for the pursuance of the aims and for the assessment of results in strategic aspects. A structured method of personnel analysis for the identification and development of intellectual capital in strategic and operational positions is still nonexistent as well.

Moreover, there is still no system for staff assessment and there is no education and training plan. The training and development of people who make up the workforce are not planned in accordance with DRA strategy and there is no adjustment of budgetary funds for this purpose. No assessment on well-being, satisfaction and motivation is carried out on DRA personnel.

As this is a Public Institution, its budgetary management is linked to the Budget of the Union and no financial resources are procured or applied. There is no comparable reference with regard to budgetary and financial results. There is no information for the assessment of perceived quality, of client satisfaction or of the service level offered to the potential universe and DRA standing. Current levels evidence positive tendencies with regard to interaction with society but there is still no comparative reference for the results.

Globally, empiric investigation has shown that there is a direct relationship between the variables "Higher Administration commitment, responsibility and participation" and quality. The importance of having satisfied collaborators, whose interests are conciliated with the interests of the organisation, is evident. Considering the initial dynamics for the implementation of the PQSP, the information collected shows that there was no previous understanding regarding the role of each one in the process. Spontaneous allegiance is essential to commitment but skills are also essential and DRA still lacks a training program for people taking part in the processes. As no institutional initiative was taken, uncertainty with regard to commitment levels and people's motivation remained, disconnected from the administrative functions. There are countless reports, crammed with huge amounts of information, but they are only used by the Top Administration. In this aspect there has been undeniable progresses in the knowledge acquired by the organisation leadership. There is a shortage of specific indicators for the DRA, because the existing ones are associated only with the objectives and needs of the higher instances.

Leadership (1) and Strategies and Plans (2) criteria alone have reached more than half the percentage of possible score with $57 \%$, because there is already some control over the items being followed and some definition of the standard procedures necessary to sustain the results. The third criterion, Citizens-Society (3), scored only 37\%, because the goals 
and the methods to reach those goals are not yet defined. This phase (criteria 1,2 and 3) is equivalent to the establishment of the control directives (Plan in PDCA). Generally, it is considered the weak point of most organisations. However, in DRA it is the strongest point, mainly because it is a public organisation, where the items and the standard procedures are a requirement of the own government.

The analysis of the People (5) and Processes (6) (Do in PDCA) criteria shows that the first one has got a very low grade, reaching only $13 \%$ of the possible evaluation. It justifies due to the lack of training for the executors. The criterion Processes attained 51\%, what is justified by the public character of the institution that force to the existence of standard procedures. The criterion Results (7) (Control in PDCA), although reaching 51\% of the total score, still has a lot to improve. Finally, the criterion Information and Knowledge (4) (Act in PDCA), has reached only $30 \%$ of the total score, being one of the weakest points of the organisation.

\section{Conclusion}

The analysis carried out in DRA concurs with various assumptions of Institutional and Neo-Institutional Theory. In fact, it seems to confirm that receiving legitimacy from the environment is the primary driver of most of the effort being made and that coercive isomorphism is an important mechanism behind the improvement processes and the change in organizational routines. The DRA seems to be incorporating the norms of the environment but, as assumed by Institutional Theory, the degree to which the norms and values are being institutionalized depends on the internal dynamics of the organization and the support provided by those in power. The involvement of the Director of the DRA and of the Pro-Rector was of fundamental importance at the onset and the development of the quality program at the DRA but some deficiencies were found in the way the message is communicated through the various organizational levels and the manner in which the organization is prepared to encounter the challenges facing it.

Regarding the methodology used in the study, we were able to identify the fundamental aspects that have intervened in the adoption of the PQSP model. Moreover, it allowed us to consider a proposal which we think may lead to a sustainable improvement in the department's performance.

The study confirms that, to a certain point, the implementation processes and the evaluation of the quality management system in the UFPel generated alterations in its processes and structure, its organizational climate and culture and in its practices. The alterations, therefore, involved the need for additional and varied efforts from all concerned. However, the nature and depth of those changes were, in the case under study and up till the present time, variable. Up to a certain point, a process of coercive isomorphism must have taken place, which appears to have been limited to the part that is visible to the exterior. Organizational inertia, however, is also markedly pronounced and springs from various sources. We can perhaps venture that in some parts of the organization isomorphism is more related with inertia than with change. Having adopted and implemented the procedures that enable it to attain minimum levels of performance, according to the criteria established by the financing entity and made its results visible to the exterior, the organisation seems to be simultaneously emulating itself, while moving slowly to respond to external demands.

The immediate question that begs asking is to what point the pressure exerted by the State is really strong with regard to the implementation and activation of the quality 
assurance systems in these universities. If it was, would the organization not be using the comparative information it has gathered to assess and compare itself with other public universities? Another question that emerges has got to do with the disparity between the effort required and the means and time available to carry it out. As the organization is impeded from implementing part of the requisites through conspicuous lack of resources, namely, information systems and staff with adequate training, it can only try to do its best in the time available, in this way attaining the basic levels necessary for its legitimization. Accordingly, more than questioning the need of implementing more efficient processes and responding more effectively to its clients needs, the organization appears to be fighting, on the one hand, to build its technological and structural capacity to respond to external impositions in the time allowed and, on the other, struggling to find its own path and keeping its own identity and the characteristics that single it out in the eyes of its clients.

In such a situation, leadership capacity and commitment to results are fundamental. Leadership is central in all total quality management implementation in higher education institutions and seems to be the most critical factor for its success (Kanji and Tambi 2002). Our results show that the success in the development of the PQSP model in the DRA strongly depends on the top administration capacity (Rector and Vice-Rector) to commit themselves to the implementation of a management system which is coherent with the institutional values and the strategic orientations. Hopefully, this will stimulate the collaborators to pursue a common purpose, committing themselves to the results. To mitigate the effects of inertia, top management must also find motivation and communication means and mechanisms with middle management and these with the other members of staff. A study conducted in England proposes a framework for the involvement of leaders that considers mission, image and values, internal and external communication, staff empowerment through participation and commitment and staff support (Osseo-Asare et al. 2005). These aspects are especially important when the new models of management and internal organization are not only imposed to respond to alterations that are external to the organization, but also presented as final products, generated without the collaboration of the workers.

Clarity in the declaration of a common purpose is vital. Everybody must have a clear idea of the goals and their justifications, the time, space, and resources needed to reach the goals and the way the processes and the results will be appraised. This is certainly a crucial aspect in need of further work at the DRA.

Incorporation of good practices must be managed and nurtured. The University is the entity that most benefits from the practices developed during the evaluation process. The procedures and the discussions, integral parts of the management system, contribute to organisational learning. This way, the incorporation of good practices contributes to process innovation and the motivation of the people involved and must be consciously assumed by the organization and managed as a true learning process.

The available knowledge strongly depends on people's motivation. The knowledge of an institution is related to the knowledge, abilities and competences of its collaborators. People with different abilities, knowledge and experiences become teams with formidable performances when participating together in planning activities. Considering that people have different needs and expectations, team performance improves when members have skills and autonomy to attain the defined goals. Therefore, it is fundamental to design, implement and evaluate training in specific technical capacities, team work, leadership and interpersonal communication and relationships, among other competencies.

Controlling the processes is mandatory. The control of key processes demands a suitable information system as well as an effective process of communication, so that the community can understand the goals, keep up with the dynamics, and evaluate the contribution 
of the unit to the institutional results. This is an urgent measure of fundamental importance at UFPel.

Following Ramos (1995), we believe that one of the solutions for Brazilian Universities would be the generation of a Brazilian model of total quality specifically designed for them. Such a proposal is guided by an innovative strategy of bottom-up transformation in each institution, aiming at improving the national education system. Quality is decided at the top but is built from the bottom, through students, teachers, leaders, administrative staff and society as a whole.

The study reported here has several limitations. Firstly, we cannot make generalizations on similar institutions from the results, since the changes that took place during the period under analysis are specific to DRA. Secondly, even if the PQSP model has been applied with maximum rigour and effectiveness, it should be considered a step in the generation of knowledge on the theme and other models can be applied to improve and consolidate the one that has been used. Thirdly, as people's perceptions change over time, there may be some distortion of reality when reporting the past. Finally, it should be remembered that the Brazilian public educational sector, specifically Higher Education, is going through considerable turbulence and uncertainty, due to economic and structural factors. At times, these aspects have facilitated the research in others they have limited the action, due to the lack of systematized material on the subject. We must also highlight the fact that the analysis was carried out in just one department, given the resources that would be necessary to put a qualitative study in place in the whole institution. The results presented in this work should be considered in the light of these limitations.

However, it is our understanding that this study has the virtue of presenting the results of the assessment of the implementation of a quality management system in an institution of higher education carried out with precision, in depth and according to the requisites imposed externally. In fact, although this theme is treated frequently and there are some works published on the matter of quality in higher education (e.g., Doherty 1993, 1997), it is also true that publications on empirical work with the characteristics of this study are very rare, as we did not find a single work with the range and depth of the present one. This is our modest contribution to the creation of a knowledge base in this area and an incentive to the publication of similar research that will analyse and discuss quality in higher education, the demands that are enforced on so many institutions of this sector and the efforts that are being made by so many of them in responding to these demands and the expectations of their stakeholders while still keeping their identity.

Open Access This article is distributed under the terms of the Creative Commons Attribution Noncommercial License which permits any noncommercial use, distribution, and reproduction in any medium, provided the original author(s) and source are credited.

\section{Appendix 1: internal documents used in the study}

Universidade Federal de Pelotas. 2002. Relatório de Gestão 2001. Pelotas: Editora Universitária.

Universidade Federal de Pelotas. 2003. Relatório de Gestão 2002. Pelotas: Editora Universitária.

Universidade Federal de Pelotas. 2004. Relatório de Gestão 2003. Pelotas: Editora Universitária.

Universidade Federal de Pelotas. 2000. Plano de Acção 2001. Pelotas: Editora Universitária. 
Universidade Federal de Pelotas. 2001. Plano de Acção 2002. Pelotas: Editora Universitária.

Universidade Federal de Pelotas. 2002. Plano de Acção 2003. Pelotas: Editora Universitária.

Universidade Federal de Pelotas. 2003. Plano de Acção 2004. Pelotas: Editora Universitária.

Universidade Federal de Pelotas. Plano Plurianual de Gestão 1998/2000. Pelotas: Editora Universitária.

Universidade Federal de Pelotas. Plano Plurianual de Gestão 2002/2005. Pelotas: Editora Universitária.

Universidade Federal de Pelotas. 2001. Catálogo de Graduação 2002. Pelotas: Editora Universitária.

Universidade Federal de Pelotas. 2002. Catálogo de Graduação 2003. Pelotas: Editora Universitária.

Universidade Federal de Pelotas. 2003. Catálogo de Graduação 2004. Pelotas: Editora Universitária.

\section{Appendix 2}

See Table 1.

Table 1 Evaluation of method and application

\begin{tabular}{|c|c|c|}
\hline Adequacy/exemplariness & Dissemination/continuity & $\%$ \\
\hline $\begin{array}{l}\text { Practices appropriate to all the requirements of } \\
\text { the item } \\
\text { Proactive practices; most of them are innovative } \\
\text { or refined }\end{array}$ & $\begin{array}{l}\text { Practices disseminated in all the areas, } \\
\text { processes, products and/or the pertinent } \\
\text { interested parts } \\
\text { Use is prolonged without hiatus or variations }\end{array}$ & 100 \\
\hline $\begin{array}{l}\text { Practices appropriated to almost all the } \\
\text { requirements of the item, and that take into } \\
\text { consideration the learning requirements } \\
\text { The majority of the practices are proactive and } \\
\text { some are innovative or refined }\end{array}$ & $\begin{array}{l}\text { Practices disseminated in all the areas, } \\
\text { processes, products and/or the pertinent } \\
\text { interested parts } \\
\text { Use is prolonged, but with some hiatus or } \\
\text { variations }\end{array}$ & $80 \pm 10$ \\
\hline $\begin{array}{l}\text { Have most of the results relevant for } \\
\text { determining the performance in the item } \\
\text { Performance is higher or equivalent to the } \\
\text { appropriate comparative information } \\
\text { presented for some important results } \\
\text { comparative information presented for some } \\
\text { important results }\end{array}$ & $\begin{array}{l}\text { Favourable tendencies in most of the relevant } \\
\text { results }\end{array}$ & \\
\hline $\begin{array}{l}\text { Have some of the results relevant for } \\
\text { determining the performance in the item } \\
\text { Performance is lower or equivalent to the } \\
\text { appropriate comparative information } \\
\text { presented for all the important results or } \\
\text { comparative information not present }\end{array}$ & $\begin{array}{l}\text { Favourable tendencies in some of the relevant } \\
\text { results or results are in initial stages of } \\
\text { development }\end{array}$ & $20 \pm 10$ \\
\hline Irrelevant results or not presented & $\begin{array}{l}\text { Unfavourable tendencies in all the relevant } \\
\text { results or tendencies are impossible to } \\
\text { evaluate }\end{array}$ & 0 \\
\hline
\end{tabular}

Adapted from the Evaluation Manual of PQSP. Ministry of Planning, 2004 


\section{Appendix 3}

\section{See Table 2.}

Table 2 Evaluation of results

\begin{tabular}{|c|c|c|}
\hline Relevance/performance & Tendency & $\%$ \\
\hline $\begin{array}{l}\text { All the relevant results for determining the } \\
\text { performance in the item are present } \\
\text { Performance is higher then the appropriate } \\
\text { comparative information presented for all } \\
\text { the relevant results, and considered an } \\
\text { excellence referential in some of them }\end{array}$ & $\begin{array}{l}\text { Tendencies are favourable in all the } \\
\text { relevant results }\end{array}$ & 100 \\
\hline $\begin{array}{l}\text { Have most of the relevant results for } \\
\text { determining the performance in the item } \\
\text { Performance is higher then the appropriate } \\
\text { comparative information in the majority of } \\
\text { the relevant results }\end{array}$ & $\begin{array}{l}\text { Tendencies are favourable in most of } \\
\text { the relevant results, without } \\
\text { unfavourable tendencies in the } \\
\text { relevant results }\end{array}$ & $80 \pm 10$ \\
\hline $\begin{array}{l}\text { Have most of the relevant results for } \\
\text { determining the performance in the item } \\
\text { Performance is higher then or equivalent to } \\
\text { the appropriate comparative information in } \\
\text { some of the relevant results }\end{array}$ & $\begin{array}{l}\text { Tendencies are favourable in the } \\
\text { majority of the relevant results }\end{array}$ & $50 \pm 10$ \\
\hline $\begin{array}{l}\text { Have some of the relevant results for } \\
\text { determining the performance in the item } \\
\text { Performance is lower then the appropriate } \\
\text { comparative information in all the relevant } \\
\text { results, or do not show comparative } \\
\text { information }\end{array}$ & $\begin{array}{l}\text { Tendencies are favourable in some of } \\
\text { the relevant results or in the initial } \\
\text { stages of development }\end{array}$ & $20 \pm 10$ \\
\hline Irrelevant results or not presented & $\begin{array}{l}\text { Unfavourable tendencies in all the } \\
\text { relevant results or tendencies are } \\
\text { impossible to evaluate } 0\end{array}$ & \\
\hline
\end{tabular}

Adapted from the Evaluation Manual of PQSP. Ministry of Planning, 2004

\section{Appendix 4}

See Table 3.

Table 3 Global score levels

\begin{tabular}{|c|c|c|c|}
\hline Level & Position & Score & Stage of the organisation \\
\hline 9 & $\begin{array}{l}\text { High } \\
\text { Medium } \\
\text { Low }\end{array}$ & $\begin{array}{l}951-1000 \\
901-950 \\
851-900\end{array}$ & $\begin{array}{l}\text { Innovative practices highly refined and completely applied. } \\
\text { Results totally related to the practices, with very } \\
\text { favourable tendencies and excellent performance levels. } \\
\text { International and national leadership, recognized as a } \\
\text { referential of excellence }\end{array}$ \\
\hline 8 & $\begin{array}{l}\text { High } \\
\text { Medium } \\
\text { Low }\end{array}$ & $\begin{array}{l}817-850 \\
784-816 \\
751-783\end{array}$ & $\begin{array}{l}\text { Very refined practices innovative and very well applied, } \\
\text { without hiatus or variations in the major areas and } \\
\text { processes. Important results, related to the practices and } \\
\text { with favourable tendencies. It is the referential of } \\
\text { excellence in the area }\end{array}$ \\
\hline
\end{tabular}


Table 3 continued

\begin{tabular}{|c|c|c|c|}
\hline Level & Position & Score & Stage of the organisation \\
\hline 7 & $\begin{array}{l}\text { High } \\
\text { Medium } \\
\text { Low }\end{array}$ & $\begin{array}{l}717-750 \\
684-716 \\
651-683\end{array}$ & $\begin{array}{l}\text { Proactive practices some of them being innovative and } \\
\text { refined, with good evidence of continuity and maturity in } \\
\text { most of the major areas and processes. There is a good } \\
\text { base for amplifying the dissemination of the implemented } \\
\text { practices, with favourable tendencies in most of the areas. } \\
\text { In some of the areas, it may be the leader or the referential } \\
\text { of excellence }\end{array}$ \\
\hline 6 & $\begin{array}{l}\text { High } \\
\text { Medium } \\
\text { Low }\end{array}$ & $\begin{array}{l}617-650 \\
584-616 \\
551-583\end{array}$ & $\begin{array}{l}\text { Practices adequate and effective in most of the requisites, } \\
\text { normally proactive and continuous, disseminated in most } \\
\text { of the principal areas and processes and without major } \\
\text { deficiencies. Tendencies are favourable in the results of } \\
\text { most of the areas important for the organisational success. } \\
\text { Performance is higher then the comparative information } \\
\text { in some of the results }\end{array}$ \\
\hline 5 & $\begin{array}{l}\text { High } \\
\text { Medium } \\
\text { Low }\end{array}$ & $\begin{array}{l}517-550 \\
484-516 \\
451-483\end{array}$ & $\begin{array}{l}\text { Practices are adequate and effective for some of the } \\
\text { requisites of all the items, being some of theme proactive } \\
\text { with continuous use in many areas and processes. } \\
\text { However, in some of them the application is still in the } \\
\text { initial stages. The tendencies are favourable and the } \\
\text { performance is superior to the comparative information in } \\
\text { some of the results }\end{array}$ \\
\hline 4 & $\begin{array}{l}\text { High } \\
\text { Medium } \\
\text { Low }\end{array}$ & $\begin{array}{l}417-450 \\
384-416 \\
351-383\end{array}$ & $\begin{array}{l}\text { Practices are adequate in most of the requisites of the items, } \\
\text { being some of them proactive. In some of the areas and } \\
\text { processes, the application is very recent to show results. } \\
\text { Tendencies are favourable but very recent in some areas } \\
\text { that are important for the organisational success. The use } \\
\text { of comparative information is in the beginning but the } \\
\text { performance is similar in some of the results }\end{array}$ \\
\hline 3 & $\begin{array}{l}\text { High } \\
\text { Medium } \\
\text { Low }\end{array}$ & $\begin{array}{l}317-350 \\
284-316 \\
251-283\end{array}$ & $\begin{array}{l}\text { Practices are adequate in most of the requisites of the items, } \\
\text { reactive and beginning to have a continuous use. } \\
\text { Meanwhile, there exist important lacunas in the methods } \\
\text { and its application in some of the criteria items. The } \\
\text { collecting of results related with the management } \\
\text { practices are in primary stages, with some favourable } \\
\text { tendencies }\end{array}$ \\
\hline 2 & $\begin{array}{l}\text { High } \\
\text { Medium } \\
\text { Low }\end{array}$ & $\begin{array}{l}217-250 \\
184-216 \\
151-183\end{array}$ & $\begin{array}{l}\text { Practices are in the first stages of development and } \\
\text { implementation, existing significant lacunas in the } \\
\text { application of most of them. Some results coming from } \\
\text { the application of implemented practices begin to appear } \\
\text { with favourable tendencies }\end{array}$ \\
\hline 1 & $\begin{array}{l}\text { High } \\
\text { Medium } \\
\text { Low }\end{array}$ & $\begin{array}{c}101-150 \\
51-100 \\
0-50\end{array}$ & $\begin{array}{l}\text { Management practices in very preliminary stages of } \\
\text { development. It cannot be said that the results are coming } \\
\text { from the implemented practices }\end{array}$ \\
\hline
\end{tabular}

Adapted from the evaluation manual of PQSP. Ministry of Planning, 2004

\section{Appendix 5}

See Table 4. 
Table 4 Results in the criteria

\begin{tabular}{lllll}
\hline Criteria & Method/Application & Exemplariness & Score \\
\cline { 2 - 3 } & Adequate Disseminated Continuous & Proactive Innovative Refined \\
\hline
\end{tabular}

1. Leadership

\begin{tabular}{|c|c|c|c|c|c|}
\hline $\begin{array}{l}\text { 1.1 System of } \\
\text { Leadership }\end{array}$ & $X$ & $X$ & $X$ & & 40 \\
\hline $\begin{array}{l}\text { 1.2 Culture of } \\
\text { Excellence }\end{array}$ & $X$ & $\mathrm{X}$ & $X$ & $X$ & 70 \\
\hline $\begin{array}{c}\text { 1.3 Global Critical } \\
\text { Analyses }\end{array}$ & $X$ & $X$ & $X$ & $X$ & 60 \\
\hline
\end{tabular}

2. Strategies and Plans

Formulation

X $\quad \mathrm{X}$

X

X

6018

2.1 Strategies
Unfolding X $\quad \mathrm{X}$

X

X

6018

Implementation

2.3 Performance X X

Evaluation

X

X

X

$50 \quad 15$

System

Formulation

Sub-total Strategies and Plans

3. Citizens-Users and Society

3.1 Image and

Mutual

Knowledge

3.2 Relationship with $\mathrm{X}$

X

X

Customers

3.3 Interaction with $\mathrm{X}$ the Society

X X

6018

Sub-total Citizens-

Users and Society

4. Information

\begin{tabular}{|c|c|}
\hline $\begin{array}{l}\text { 4.1 Organisational } \\
\text { Information } \\
\text { Management }\end{array}$ & $X$ \\
\hline $\begin{array}{l}\text { 4.2 Comparative } \\
\text { Information } \\
\text { Management }\end{array}$ & $\mathrm{X}$ \\
\hline $\begin{array}{l}\text { 4.3 Intellectual } \\
\text { Capital } \\
\text { Management }\end{array}$ & $\mathrm{X}$ \\
\hline
\end{tabular}

Sub-total Information

5. People Management

5.1 Work System $\quad X \quad X \quad X$
5.2 People Training
and Development
5.3 Quality of Life

$40 \quad 12$

$0 \quad 0$

00 
Table 4 continued

\begin{tabular}{lllll}
\hline Criteria & Method/Application & Exemplariness & Score \\
\cline { 2 - 3 } & Adequate Disseminated Continuous & Proactive Innovative Refined \\
\hline
\end{tabular}

Sub-total People

Management

6. Processes

\begin{tabular}{|c|c|c|c|c|c|}
\hline $\begin{array}{l}\text { 6.1 Excellence } \\
\text { Management }\end{array}$ & $X$ & $X$ & $X$ & & 40 \\
\hline $\begin{array}{l}\text { 6.2 Support } \\
\text { Processes } \\
\text { Management }\end{array}$ & $X$ & $X$ & $X$ & & 40 \\
\hline $\begin{array}{l}\text { 6.3 Supply Processes } \\
\text { Management }\end{array}$ & $X$ & $X$ & $X$ & $X$ & 60 \\
\hline $\begin{array}{l}6.4 \text { Financial } \\
\text { Management }\end{array}$ & $X$ & $X$ & $X$ & $X$ & 70 \\
\hline
\end{tabular}

\begin{tabular}{|c|c|c|c|c|c|}
\hline & Relevance & Performance & Tendency & & \\
\hline \multicolumn{6}{|l|}{ 7. Results } \\
\hline 7.1 Results Related to Users & No & - & - & 0 & 0 \\
\hline 7.2 Results Related to Society & Yes & + & + & 60 & 30 \\
\hline 7.3 Results Related to Finances & No & - & - & 30 & 18 \\
\hline 7.4 Results Related to People & Yes & + & + & 60 & 36 \\
\hline 7.5 Results Related to Supplies & Yes & + & + & 80 & 32 \\
\hline 7.6 Results Related to Products & Yes & + & + & 80 & 72 \\
\hline 7.7 Results Related to Processes & Yes & + & + & 80 & 48 \\
\hline Sub-total Results & & & & & 256 \\
\hline Total & & & & & 456 \\
\hline
\end{tabular}

\section{References}

Barçante, L. C. (1998). Qualidade Total: uma visão brasileira. Rio de Janeiro: Campus.

Bell, E., \& Taylor, S. (2005). Joining the club: The ideology of quality and business school badging. Studies in Higher Education, 30(3), 239-255. doi:10.1080/03075070500095671.

Birnbaum, R. (1988). How colleges work: The cybernetics of academic organization and leadership. JosseyBass, Inc: San Francisco.

Cohen, M., \& March, J. (2000). Leadership in an organized anarchy. In M. C. Brown (Ed.), Organization and governance in higher education (5th ed.). Boston: Pearson Custom Publishing.

Deming, W. E. (1986). Out of the crisis. Cambridge: MIT Press.

DiMaggio, P., \& Powell, W. (1983). The iron cage revisited: Institutional isomorphism and collective rationality in organizational fields. American Sociological Review, 48, 147-160.

DiMaggio, P., \& Powell, W. (1991). The new institutionalism in organizational analysis. Chicago: The University of Chicago Press. 
Doherty, G. D. (1993). Towards Total Quality Management in higher education: A case study of the University of Wolverhampton. Higher Education, 25(3), 321-339. doi:10.1007/BF01383857.

Doherty, G. D. (1997). Quality, standards, the consumer paradigm and developments in higher education. Quality Assurance in Education, 5(4), 239-248. doi:10.1108/09684889710189129.

Drucker, P. (1993). Post-capitalist society. New York: Harpercollins.

Flexner, A. (1930). Universities-American, English, German. New York: Oxford University Press. Republished in 1968 with a preface by Clark Kerr.

Freitag, B. (1986). Escola, Estado e Sociedade. São Paulo: Ed.Moraes.

Kanji, G. K., \& Tambi, A. M. (2002). Business excellence in higher education. Chichester: Kingsham.

Meyer, V. (1997). Gestão para a qualidade e qualidade na gestão: o caso das universidades. Seminário da Qualidade em Universidades. Florianópolis: Universidade Federal de Santa Catarina.

Meyer, J. W., \& Rowan, B. (1991). Institutionalized organizations: Formal structure as myth and ceremony. In W. W. Powel \& P. DiMaggio (Eds.), The new institutionalism in organizational analysis (pp. 4162). Chicago: The University of Chicago Press.

Ministério do Planejamento, Orçamento e Gestão. (2004). Manual de Avaliação do PQSP. MPOG.

Mintzberg, H. (1979). The structuring of organizations: A synthesis of the research. Englewood Cliffs, NJ: Prentice-Hall.

Niskier, A. (2000). Membro da Academia Brasileira de Letras, in Doutrina da Educação. São Paulo: Folha dirigida.

Osseo-Asare, A. E., Longbottom, D., \& Murphy, W. D. (2005). Leadership best practices for sustaining quality in UK higher education from the perspective of the EFQM Excellence Model. Quality Assurance in Education, 13(2), 148-170.

Powell, W., \& DiMaggio, P. (Eds.) (1991). The new institutionalism in organizational analysis. Chicago: The University of Chicago Press.

Ramos, C. (1995). Sala de aula de Qualidade Total. Rio de Janeiro: Qualitymark.

Romanelli, O. (1991). História da educação no Brasil. Petrópolis: Vozes.

Schwartzman, S. (1993). A Qualidade no Espaço Universitário: Conceitos, Modelos e Situação Actual. I Congresso Internacional Qualidade e Excelência na Educação, Rio de Janeiro, 25-29 de Outubro.

Scott, W. R. (1987). The adolescence of institutional theory. Administrative Science Quarterly, 32(4), 493511. doi:10.2307/2392880.

Scott, W. R. (1995). Institutions and organizations. Thousand Oaks, CA: Sage Publications.

Scott, W. R. (1998). Organizations: Rational, natural, and open systems (3rd ed.). Upper Saddle River, NJ: Prentice Hall.

Tubino, M. (1998). A qualidade no ensino superior. Parceria em Qualidade. Rio de Janeiro: Qualitymark Editora. Ano 6, 28/29.

Weick, K. (1976). Educational organizations as loosely coupled systems. Administrative Science Quarterly, $21,1-19$.

Yin, R. (2003). Applications of case study research. London: Sage.

Zucker, L. G. (1977). The role of institutionalization in cultural persistence. American Sociological Review, 42, 726-743. 